\title{
EXHAUSTION OF ADMINISTRATIVE REMEDIES
}

\section{BY RAOUL BERGER $†$}

ADMINISTRATIVE remedies must be exhausted before resort is had to the federal courts. The doctrine is as old as federal administrative law, ${ }^{1}$ and in the fifty years that have elapsed since the early decisions it has been expounded in a formidable mass of case law. Yet there remain doubts which continue to engender litigation as to the application of what is essentially a simple rule of procedure. It is not as if the exhaustion doctrine presented profound legal or social problems. The rule merely involves a policy of orderly procedure which favors a preliminary administrative sifting process, a policy which is best effectuated by a simple, unvarying practice. Such a practice might do away with the spectacle of preliminary litigation to decide whether a court or administrative tribunal should in the first instance determine, for example, whether "Ry-Krisp" is a "cooked cereal food" or "bakery goods." " It is the purpose of this article to explore several of the areas within the exhaustion doctrine in which uncertainty prevails, and to examine the historical bases of and the policies behind the rule, with the hope of clarifying the objectives and consequently the application of the rule.

I.

Commonly identified with Prentis v. Atlantic Coast Line Railacay, ${ }^{3}$ the exhaustion doctrine in fact antedates that case. It is first met in tax cases arising in the lower federal courts in which injunctions were refused because the complainant had neglected to avail himself of the redress that a board might furnish against an allegedly illegal assessment. ${ }^{4}$ A definitive formulation of the doctrine by the Supreme Court

†General Counsel's Staff, Securities and Exchange Commission.

1. Federal administrative law may be said to have taken shape with the advent of the Interstate Commerce Commission in 18S7. The earliest manifestation of the exhaustion doctrine is found in Dundee Mortgage Trust Inv. Co. v. Cliarlton, 32 Fed. 192 (C. C. D. Ore. 1887) (injunction denied where no appeal was taken from tax assessor to state board) ; Altschul v. Gittings, 86 Fed. 200 (C. C. D. Ore. 1898).

2. Great Northern Ry. v. Ry-Krisp Co., 4 F. Supp. 358, 365 (D. Minn. 1933) ("the question presented is one peculiarly for the commission to determine preliminarily before this court could assume jurisdiction.")

3. 211 U. S. 210 (1908); see Lilienthal, The Federal Courts and Slate Regulation of Pablic Utilitics (1930) 43 Harv. L. Rev. 379, 385: Alpert, Suils Alyainst Administrotize Agencies Under N.I.R.A. and A.A.A. (1935) 12 N. Y. U. L. Q. Rev. 393, 395; Comment (1938) 51 HARv. L. REv. 1251, 1261 ; Gildhrist v. Interborough Rapid Transit Co., 279 U. S. 159, 208 (1929).

4. Dundee Mortgage Trust Inv. Co. v. Charlton; Altschul v. Gittings, supra note 1. There is language in Altschul v. Gittings (p. 202) from which it might be inferred that the court felt bound by the state statute, which imposed upon the taxpayer a duty of seeking administrative relief, to bar the complainant. No state statute an, of course, 
had also been enunciated in an immigration case, Unitcd States $v$. Sing Tuck. ${ }^{5}$ That case arose on a petition for habeas corpus, and the Court denied relief because the petitioner had failed to follow the statutory provision for appeal from the immigration official to the Secretary of Commerce and Labor. Mr. Justice Holmes declared that the act "points out a mode of procedure which must be followed before there can be a resort to the courts." 6

The Prentis case marks an extension of the exhaustion doctrine insofar as it requires a litigant to exhaust his right of appeal from a state commission to a state legislative court as a preliminary to relief by a federal court. At the same time, however, the decision represents a refinement of a different and earlier rule, the rule that courts will not enjoin the process of legislation. ${ }^{7}$ In the Prentis case legislative rate making had been initiated by a Commission which promulgated a rate, for which, so the statute provided, the state Supreme Court might on appeal substitute its own order. This corrective power was deemed by the United States Supreme Court legislative in nature, and it therefore decided that a federal injunction directed to the Commission should be withheld until the State, acting through its highest court, completed its legislative action. ${ }^{8}$ The postponement of judicial relief until the state

have the effect of limiting the jurisdiction of federal courts. In a case arising in a federal court, where the state statute provided "that no such injunction shall be awarded unless application be first made to the auditor to correct the mistake claimed, and the auditor shall refuse to do so," the Supreme Court said, "While this provision cannot, of course, bind the courts of the United States, it is nearly in accord with the rule governing the exercise of the jurisdiction in equity of those courts . . ." (italics supplied). Pittsburgh Ry. v. Board of Public Works, 172 U. S. 32, 47 (1898).

5. 194 U. S. 161 (1904).

6. Id. at 167 .

7. Reagan v. Mercantile Trust Co., 154 U.S. 362, 413 (1894) (refusal to restrain railroad commission from "proceeding to establish reasonable rates and regulations") ; New Orleans Water Works v. New Orleans, 164 U. S. 471 (1896) (refusal to enjoin passuge of ordinance); McChord v. Louisville \& Nashville Ry., 183 U. S. 483 (1902) (refusal to enjoin fixing of rates by Commission).

8. In Pittsburgh Ry. v. Board of Public Works, 172 U. S. 32, 45 (1898), the Supreme Court had taken note of the possibility that a court might, in the excrcise of a power to correct the assessment of a board, be employing administrative rather than judicial power.

The revisory power, the "power to promulgate another order to take the place of the one stricken down," which is said to be the distinguishing characteristic of a "legislative" court [Kansas City So. Ry. v. Cornish, 65 F. (2d) 671,673 (C. C. A. 10th, 1933 ) ] is expressly granted in the constitutions of only two states, Virginia (Art. XII, $\S 156(\mathrm{~g})$ and Oklahoma (Art. IX, $\S 23$ ). For statutory provisions, sce Arizons Rev. Code Ans. (Struckmeyer, 1928) §720; Colorado Stat. Awn. (Michie, 1935) c. 137, $\$ 52$; Louisiana Gen. Stat. Ans. (Dart, 1932) \$7937. And see Van Buren Water Co. v. Van Buren, 152 Ark. 83, 237 S. W. 696, 698 (1922), and Porter v. Investors Syndicite, 286 U. S. 461 (1932), which respectively construe an Arkansas and a Montana statute to permit the state court to substitute its own order for, or modify, the administrative order, thus creating "legislative" review. 
takes "final legislative action" rests not alone on the disinclination of the judiciary to interfere with the exercise of the legislative power, ${ }^{10}$ but on the fact that no harm can result until the legislation takes definite form; or, as the Supreme Court has said in denying an injunction against the fixing of rates by a Commission, "none of the consequences alleged to be threatened can be set up as the basis of equity interposition before the rates are fixed at all." 11 This formulation underlies the analogous cases, frequently cited for the exhaustion doctrine, in which the court refuses to enjoin an administrative official from performing his statutory duties on the ground that until he has acted the complainant can show no more than an apprehension that he will perform his duty wrongly, a fear that courts will not allay. ${ }^{12}$ Such cases may be expressed in the formula that judicial intervention is premature in the absence of administrative action. ${ }^{13}$ But doctrinal lines of demarcation have apparently been unnoticed, ${ }^{14}$ and there has been a confluence of the various sources, from which a broad exhaustion doctrine may be said to have evolved. Today the various categories of cases are lumped together as authority for widespread application of the rule. ${ }^{15}$

The development of the doctrine has largely been shaped by three factors: the need for orderly procedure, the requirements of comity, and the tendency to assimilate the doctrine to the rule that a litigant has no standing in equity where he has an adequate remedy at law.

The necessity for orderly procedure in the administrative process was first proclaimed by Mr. Justice Holmes in a case wherein judicial relief

9. 211 U. S. 210 , at 230 (1908). The criteria for distinguishing between legislative and judicial functions of a court (see Comment (1934) I U. of Crr. L. REv. 777) have proven to be a far from infallible touchstone; and the unwary litigant who fails properly to gauge the capacity in which the state court functions is likely to find himself barred by a plea of res judicata. Dorrance v. Martin, 12 F. Supp. 746 (D. X. J. 1935).

10. See note 7, supra.

11. McChord v. Louisville \& Nashville Ry., 183 U. S. 483, 502 (1902).

12. First National Bank v. Albright, 208 U. S. 548, 553 (1908); Dalton Machine Co. v. Virginia, 236 U. S. 699, 701 (1915) ; Pacific Tel. \& Tel. Co. v. Seattle, 391 U. S. 300, 304 (1934). And see Gundling v. Chicago, 177 U. S. 183, 185 (1900).

13. That the distinction between these cases and the cases in which 3 litigant has ignored an available administrative remedy may on occasion be more than verbal is disclosed in Pacific Tel. \& Tel. Co. v. Seattle, 291 U. S. 300, 304 (1934) : "The decision of the state court must be affirmed, not because the appellant has iailed to exhaust its administrative remedies, which would concern us only if the suit had been brought in a federal court of equity, but because without administrative action, which has not occurred, there can be no infringement of the immunity invoked."

14. The cases have an air of being conceived in acuo; the leading tax cases, Farncomb v. Denver, 252 U. S. 7 (1920); and Milheim v. Mfoffat Tunnel District, 262 U. S. 710 (1923) for example, make no mention of United States v. Sing Tuck, 194 U. S. 161 (1904), or of the Prentis case. Indeed the Prentis case has itself been deemed a product of spontaneous generation. See Lilienthal, supra note 3 , at 385 .

15. See Myers v. Bethlehem Shipbuilding Corp., 303 U. S. 41, 51, n.9 (1938). 
was withheld because of the failure to appeal to a fecleral exccutive officer. Despite the argument that the administrative officer was without jurisdiction, Mr. Justice Holmes insisted upon exhaustion of the alministrative remedy, declaring that "it is one of the necessities of the alministration of justice that even fundamental questions should be determined in an orderly way." 10 The requirement of orderly procedure had been formulated in the habeas corpus cases arising out of state commitments, ${ }^{17}$ and these cases subsequently furnished Mr. Justice Holmes with an analogy in formulating the Prentis doctrine. ${ }^{18}$ Empliasis upon orderly procedure serves to preserve the advantages of a "preliminary sifting process" 10 by a tribunal specially equipped to deal with problems that are often of great technical complexity. ${ }^{20}$ It further serves to preclude efforts "to swamp the courts by a resort to them in the first instance," 21 a factor that becomes increasingly important as the stcadily growing stream of litigation makes it important to divert, ${ }^{22}$ if only temporarily, those controversies for which administrative remedies have been provided. And there is always the possibility that the action of the administrative officer or board may render resort to the courts unnecessary, for a board may decide that the issue lies outside of its jurisdiction, or a superior administrative body may on appeal correct the error complained of.

The place of comity in the history of the exhatistion doctrine is of more than academic interest, because as a rule of comity the application of the doctrine may be thought to lie within the discretion of the court, whereas if the doctrine is more closely related to the chancery rule that relief is unavailable in the presence of an adequate remedy, the rule then becomes one of equity jurisdiction. There has been a tendency to emphasize the importance of the role played by comity in the development of the exhaustion doctrine. It "must be remembered," said the

16. United States v. Sing Tuck, 194 U. S. 161, 168 (1904).

17. Urquhart v. Brown, 205 U. S. 179, 181 (1907); Mooney v. Holohan, 294 U. S. 103, 115 (1935).

18. 211 U. S. 210,229 (1908).

19. United States v. Sing Tuck, 194 U. S. 161, 170 (1904); Federal Trade Commission v. Claire Furnace Co., 274 U. S. 160, 174 (1927).

20. The contribution towards efficiency of preliminary resort to expert administrativo examination has received its greatest recognition in the Interstate Commerce Commission cases. See Great Northern Ry. v. Merchants Elevator Co., 259 U. S. 285, 291 (1922); Board of Railroad Comm's v. Great Northern Ry., 281 U. S. 412, 424 (1930) ; 2 SirARFaran, The Interstate Comarerce Cosmission (1931) 405; Armstrong v. United States, 16 F. (2d) 387, 389 (C. C. A. 8th, 1926).

21. United States v. Sing Tuck, 194 U. S. 161, 170 (1904); United States Navigation Co. v. Cunard S. S. Co., 50 F. (2d) 83, 91 (C. C. A. 2d, 1931).

22. For discussion of the problems raised by increased federal litigation see Franl:furter, Distribution of Judicial Power Betwecn United States and State Courts (1928) 13 CORN. L. Q. 499, passim. 
Supreme Court in Railroad Commission a. Duluth Strect Railany,,3 "that the requirement that state remedies be exhausted is not a fundamental principle of substantive law but merely a requirement of convenience or comity." So far as the facts of the Duluth case, which involved the question of exhausting an appeal from a commission to a state court, are concerned, the statement of the Court has a sound historical basis. For the extension of the exhaustion requirenent to the situation where appeal lies from a board to a court acting legislatively was to a large extent rested in the Prentis case on "considerations of comity and convenience."24 While the extension of the doctrine to the peculiar situation presented in the Prontis case may therefore be rested upon considerations of comity, and while the application of the rule undeniably has "special force when resort is had to the federal courts to restrain the actions of state officers," 25 it is suggested that the earlier applications of the rule to state administrative bodies were based not so much upon considerations of comity ${ }^{20}$ as upon the theory that resort to equity is premature in the absence of administrative action, ${ }^{2 \pi}$ or so long as some other remedy is available.

The tendency to assimilate the presence of an administrative remedy to the availability of an adequate remedy at law, clearly articulated in the later cases, ${ }^{28}$ made itself felt from the outset. ${ }^{20}$ From the beginning,

23. 273 U. S. $625,62 S$ (1927).

24. 211 U. S. 210,229 (1908).

25. Natural Gas Pipeline Co. v. Slattery, 302 U. S. 300,311 (1938); Lawrence v. St. Louis-San Francisco Ry., 274 U. S. 588,595 (1927).

26. The direct progenitors of the Prentis case, cases in which the courts refused to enjoin the process of legislation by state agencies, make no mention of comity. Sce note 7, supra.

27. Gundling v. Chicago, 177 U. S. 183, 186 (1900): San Diego Land and Town Co. v. Jasper, 189 U. S. 439, 441 (1903) ; First National Bank v. Albright, 20 C. S. 54S, 553 (1908).

28. It was held with reference to the National Labor Relations Act that the administrative procedure and review provided by the act furnishes " 3 piain, adequate and complete remedy at law." Elliott v. El Paso Electric Co., 88 F. (2d) 505, 505 (C. C. A. 5th, 1937) ; Pratt v. Oberman \& Co., S9 F. (2d) 786, 787 (C. C. A. Sth, 1937); Precision Castings Co. v. Boland, 85 F. (2d) 15, 16 (C. C. A. 2d, 1936). And sse Royal Balking Powder Co. v. Federal Trade Comm., 32 F. (2d) 966, 968 (App. D. C. 1929); De Paus: University v. Brunk, 53 F. (2d) 647, 652 (W. D. Mo. 1931); Baltimore \& Ohio Ry. v. Board of Public Works, 17 F. Supp. 170, 173 (N. D. W. Va. 1936); MeDermott v. Bradford, 10 F. Supp. 661, 664 (WW. D. Wash. 1935).

It is worth noting that the language of "exhaustion" creeps into the sases where a simple contract creditor is said to have "no right whatsoever in equity until he has exhausted his legal remedy." Pusey \& Jones Co. v. Hanssen, 261 U. S. 491, 497 (1923); Bailey v. George, 259 U. S. 16, 20 (1922). See also Matthews v. Rodgers, 284 U. S. 521 (1932).

29. See note 30, infra: And see quotation from Pittsburgh Ry. v. Board of Public Works, 172 U. S. 32 (1898) at note 4, supra. The case is eited by Mrr. Justice Brandeis in Myers v. Bethlehem Shipbuilding Corp., 303 U. S. 41, 51, n.9 (1938). 
the exhaustion rule was formulated in terms of equity jurisdiction, that is to say, a litigant who failed to avail himself of administrative avenues of redress could not "maintain a suit in equity." 30 And the cases lave again and again pointed out that there is no jurisdiction in equity in the absence of exhaustion of the administrative remedy. Thus, where a plaintiff "failed to avail itself of the administrative remedy" it "was not entitled to maintain a bill in equity" $;{ }^{31}$ or as another court put it, "if there is an adequate administrative remedy . . . that is sufficient to defeat federal equity jurisdiction." 32 Yet despite the frequency with which it has been indicated that the absence of prior administrative resort compels the dismissal of a suit in equity, it is still not entirely clear whether application of the rule rests within the discretion of the court or is non-discretionary. At the last term of the Supreme Court, it was intimated by way of dictum in Natural Gas Pipeline Company $v$. Slattery that the issuance of an injunction in the presence of an available administrative remedy lies within the discretion of the trial court, ${ }^{33}$ whereas $\mathrm{Mr}$. Justice Brandeis at the same term of court declared that the entry of an injunction under such circumstances constitutes an "improvident exercise of judicial discretion," and that the exhaustion doctrine is "not merely a rule governing the exercise of discretion," but "is one of judicial administration." 34 It is suggested that the latter view may find a broad base

30. Dundee Mitge. Trust Inv. Co. v. Charlton, 32 Fed. 192, 195 (C. C. D. Ore. 1887); Altschul v. Gittings, 86 Fed. 200, 202 (C. C. D. Ore. 1898); Brown v. Drain, 112 Fed. 582, 591 (C. C. S. D. Cal. 1901).

31. Gorham Mfg. Co. v. State Tax Comm., 266 U. S. 265, 270 (1924).

32. De Pauw University v. Brunk, 53 F. (2d) 647, 652 (W. D. Mo. 1931), aff'd, 285 U. S. 527 (1932) (per curiam: "The Court being of opinion that there is no jurisdiction in equity, the order of the District Court dismissing the bill of complaint in this cause is affirmed.") And see Federal Trade Commission v. Claire Furnace Co., 274 U. S. 160, 174 (1927) ("That right being adequate, they were not in a position to ask: relief by injunction. The bill should have been dismissed for zeant of equity"); Western Powder Mfg. Co. v. Interstate Coal Co., 5 F. Supp. 619, 621 (E. D. III. 1934) ("the court has no jurrisdiction of such controversies until the administrative remedies have been exhausted.") See also United States v. Illinois Central Ry., 291 U. S. 457, 463 (1934); Utley v. St. Petersburg, 292 U. S. 106, 109 (1934); Western \& Atlantic R. R. v. Georgia Public Serv. Comm., 267 U. S. 493, 497 (1925); Kansas City So. Ry. v. Cornish, 65 F. (2d) 671 (C. C. A. 10th, 1933); Schermerhorn v. Holloman, 74 F. (2d) 265, 266 (C. C. A. 10th, 1935) ; Baltimore \& Ohio Ry. v. Board of Public Works, 17 F. Supp. 170, 173 (N. D. W. Va. 1936) ; Royal Baking Powder Co. v. Federal Trade Comm., 32 F. (2d) 966 (App. D. C. 1929); Richmond Hosiery Mills v. Camp, 7 F. Supp. 139, 142 (N. D. Ga. 1934) ; McDermott v. Bradford, 10 F. Supp. 661, 664 (W. D. Wash. 1935); Stanley v. Peabody Coal Co., 5 F. Supp. 612, 617 (S. D. Ill. 1933).

33. 302 U. S. 300,311 (1938) ; United States v. Abilene \& So. Ry., 265 U. S. 274, 282 (1925).

34. Myers v. Bethlehem Shipbuilding Corp., 303 U. S. 41, 51, n.9 (1938). The doubt engendered by the Slattery and Myers decisions is noted in Red River Broadcasting Co. v. Federal Communications Commission, 98 F. (2d) 282, 284 (App. D. C. 1938) where the Myers case is cited among others for the proposition: "Generally, the rule is 
in the cases which declare that the availability of an administrative remedy is an element of equity jurisdiction. ${ }^{35}$ Equitable relief is extraordinary relief, invoked because of the absence of an adequate remedy at law, and an objection to the jurisdiction in equity on the ground that the legal remedy is adequate demands dismissal of the suit. ${ }^{30} \mathrm{By}$ analogy" "no cause of action in equity is stated" where the administrative remedy is not exhausted. ${ }^{38}$ This is not to say that administrative exhaustion is completely assimilated to an adequate remedy at law, for, while the inquiry into the adequacy and efficiency of the legal remedy is always pertinent, there is far less need to emphasize the adequacy of the administrative remedy. Insistence upon prior administrative resort is at most preliminary to judicial action, and the litigant who is sent back to an administrative tribunal can return for equitable relief. Not so the litigant who is remitted to his remedy at law, for the legal remedy may constitute final judicial action, and the litigant may upon his return to equity be faced by a plea of res judicata, even in those situations in which equity will assist the litigant to obtain the fruits of his judgment at law. For a court of chancery will not, except for fatal jurisdictional flaws, go behind the judgment, whereas a reviewing court is free to examine the administrative record. Limitations upon the scope of judicial review of administrative findings of fact at times lend such findings an aspect of finality, but the court is at least free to determine whether the findings are supported by the evidence, and it is entirely free to substitute its own findings of law.

Moreover, statement of the exhaustion doctrine in terms of an adequate remedy at law ${ }^{39}$ is misleading because emphasis is placed not so much on the comparative inadequacy as on the almost complete absence of the administrative remedy. Thus, in one case, ${ }^{10}$ no exhaustion was required

stated as being conclusive of the rights of one who prematurely seeks judicial review, without intimation or suggestion that any judicial discretion is involved in its applieation," but attention is also called by the court to the cases cited supro note 33. See also Gilchrist v. Interborough Rapid Transit Co., 279 U. S. 159, 207, 208 (1929).

35. See note 32, supra.

36. Section 16 of the Judiciary Act of 1789 [REv. Srat. $\$ 723$ (1875) 28 U. S. C. $\$ 384$ (1934)] provides that "Suits in equity shall not be sustained in any court of the United States in any case where a plain, adequate, and complete remedy may be lasd at law." This section is merely declaratory of the equity rule. Mfatthews v. Rodgers, 284 U. S. 521, 524 (1932).

37. See United States v. Illinois Central Ry., 291 U. S. 457, 463 (1934); Bradley v. Richmond, 227 U. S. 477,485 (1913).

38. Shapiro v. Lyle, 30 F. (2d) 971,973 (W. D. Wash. 1929); see note 32, sufra.

39. Nelson v. First National Bank, 42 F. (2d) 30, 31 (C. C. A. Sth, 1930); De Pauw University v. Brunk, 53 F. (2d) 647 (W. D. Alo. 1931). Note that the cmployment of the terminology of "adequate remedy" further assimilates the jurisdictional aspect of the availability of the administrative remedy to the presence of an adequate remedy at law.

40. Brotherhood Co-op. Nat. Bank v. Hurlburt, 21 F. (2d) 85, \&S (D. Ore. 1927). 
because it was beyond the power of the administrative authorities to grant relief in the absence of authority to equalize taxation by assessing notes and bonds exempt by law. In another case, ${ }^{41}$ where the grievance was that other taxpayers were illegally taxed too low, the administrative renedy was held inadequate because of the shortness of time available for investigation, and the difficulty of ascertaining the names of those who were thus assessed on a different basis so that in effect the plaintiff was barred from the administrative remedy. Unreasonable delay by the administrative body in deciding has also moved courts to dispense with the exhaustion requirement. ${ }^{42}$ In the main, therefore, the grounds for declaring an administrative remedy inadequate have been far less comprehensive than those that may be advanced in the case of a remedy at law. ${ }^{43}$ But even this relatively limited inquiry into the adequacy of the administrative remedy has in one federal circuit engendered doubts and litigation which considerably diminish the effectiveness of what should be a simple rule of administration. ${ }^{44}$

The questions of whether an application for an administrative relearing is a necessary element of exhaustion, and whether exhaustion is required where it is anticipated that administrative action will be unfavorable have likewise given rise to uncertainty. In an early case, Vandalia Railroad Company v. Public Service Commission, ${ }^{40}$ which involved an Indiana statute declaring that "the Commission shall have authority" to grant a rehearing, ${ }^{46}$ the Supreme Coturt held that a failure to apply for an administrative rehearing precluded resort to the courts. A few years later, in Prendergast $v$. New York Telephone Company, ${ }^{47}$

41. Munn v. Des Moines National Bank, 18 F. (2d) 269 (C. C. A. Sth; 1927); also see Nelson v. First National Bank, 42 F. (2d) 30, 31 (C. C. A. 8th, 1930).

42. Smith v. Illinois Bell Telephone Co., 270 U. S. 587, 591 (1926) ; Belt Line Ry. v. Newton, 273 Fed. 272 (S. D. N. Y. 1921). But see American Mutual Liability Insurance Co. v. McDonough, 61 F. (2d) 558, 560 (C. C. A. 7th, 1932),

43. For problems in connection with adequate remedy at law see $21 \mathrm{C} . \mathrm{J}$. 50 , ct seq.

44. Munn v. Des Moines Natl. Bank, 18 F. (2d) 269 (C. C. A. Sth, 1927) ; Nelson v. First Natl. Bank, 42 F. (2d) 30 (C. C. A. 8th, 1930) ; Knowles v. First Natl. Bank, 58 F. (2d) 232 (C. C. A. 8th, 1932); Crawford County Trust \& Savings Bank v. Crawford County, 66 F. (2d) 971 (C. C. A. 8th, 1933); Hamerstrom v. Toy National Bank, 81 F. (2d) 628 (C. C. A. 8th, 1936). These cases were concerned with the adequacy of the Iowa administrative remedy to relieve against discriminatory state taxation of a bank. A situation which leads litigants to appeal five times in nine years to the same Court of Appeals to determine whether exhaustion is necessary under these circumstances would seem to indicate the desirability of a practice less likely to generate uncertainty and breed litigation.

45. 242 U. S. 255,260 (1916).

46. INd. Rev. Stat. (Burns, 1908) §5537; Acts of 1907, subd. (c), p. 454, §7.

47. 262 U. S. 43, 48 (1923), distinguishing Palermo Land and Water Co. v. R. R. Commission, 227 Fed. 708 (N. D. Cal. 1915) on the ground that the statute there involved provided that no action should accrue in the absence of a petition for an administrative rehearing. See also Chicago Ry. v. Illinois Commerce Comm., 277 Fed. 970, 974 (N. D. Ill. 1922). 
the Supreme Court, making no mention of the T"andalia case, declared that exhaustion was unnecessary where the statute did not require an application for a rehearing. As a result, courts have demanded an application for an administrative rehearing as a preliminary to judicial relief only where the statute required such an application. ${ }^{\text {is }}$ A departure from these cases was recently indicated in Red Ricer Broadcusting Company r. Fideral Communications Commission, where it was held that an omission to apply for a rehearing under a permissive statute constituted a failure to exhaust the administrative remedy. ${ }^{49}$ Insistence upon an application to the administrative body for a rehearing as an element of exhaustion can be urged upon several grounds. It is consonant with the recent policy of Congress, as exemplified in several instances by a statutory bar to judicial review in the absence of an application for an administrative rehearing. The Federal Power Act, for example, declares that "No proceeding to review any order of the Commission shall be brought by any person unless such person shall have made application to the commission for a rehearing thereon." "so With reference to one such provision, it was said in another recent case that the purpose of Congress in $\mathrm{cm}-$ ploying such language "was apparently to secure to the Commission an opportunity to correct its errors when attention is properly called thereto." ${ }^{31}$ The possibility of erring is of course not confined to the administrative bodies for whom such opportunities to correct their errors are expressly provided. And insofar as an administrative body can be prevailed upon to correct its errors resort to the courts becomes unnecessary. It is this consideration which has influenced the courts in a parallel line of cases to require prior resort to an administrative body for modification of its rules and regulations as a preliminary to judicial relief.52 Presumably administrative rules and regulations are promulgated after

48. Banton v. Belt Line Ry., 268 U. S. 413, 416 (1925) ; Culumbia Gas \& Elec. Cu. v. Blease, 42 F. (2d) 463, 465 (D. S. C. 1927): Pender County v. Garysburg Mifg. Co., 50 F. (2d) 732 (C. C. A. 4th, 1931) ; cf. United States F. \& G. Co. v. Blankenhorn, 22 F. (2d) 574,576 (N. D. Cal. 1927).

49. 98 F. (2d) 282, 287 (App. D. C. 1938), cert. denied, 59 Sup. Ct. 80 (U. S. 1938 ). The pertinent statute provided that after any decision by the Commission any party "may at any time make application for rehearing of the same . . . and it shall be lawiul for the Commission in its discretion to grant such a rehearing ..."

50. Section 313a (16 U. S. C. A. \$ \$25, 1(a) Supp. 1938).

51. Mallory Coal Co. v. National Bituminous Coal Commission, 99 F. (2d) 399 (App. D. C. 1938). The Brruarrous Codr Acr (1937) (15 U. S. C. A. \$ \$36(b) Supp. 1938), provides that "No objection to the order of the Commission shall be considered by the court unless such objection shall have been urged below." This provision was held in the Mallory case to require an application for an administrative rehearing. For parallel provisions see Securrties AcT of 1933, as amended, 15 U. S. C. $\$ 77 i(a)$ (Supp. 1937); Securitres Exchange Act of 1934, 15 U. S. C. \$7Sy (a); Pedlic Utilutr Holnisg CoMpany Act of 1935, 15 U. S. C. $\$ 79 x$ (a) (Supp. 1937).

52. Petersen Baking Co. v. Bryan, 290 U. S. 570 (1934); Red "C" Oil Mrfg. Co. v. Board of Agriculture, 222 U. S. 380 (1912). 
due deliberation. Yet an appeal to the administrative body for modification of a rule is required because, as the Supreme Court recently remarked, "there is the possibility of removal of these issues from the case by modification of its order." ${ }^{3}$ The same possibility that administrative self-modification may remove the occasion for resort to the courts should influence the courts to insist upon an application for an administrative rehearing as a prerequisite to judicial relief. ${ }^{54} \mathrm{~A}$ clear-cut requirement that application for an administrative rehearing must be made in each instance would remove the doubts that have frequently encouraged litigation on this score in the past. ${ }^{55}$ To leave the application of the requirement in the realm of discretion is to depart from the rationale of the exhaustion rule. And a practice which requires a prior judicial determination in each instance as to whether an administrative rehearing is necessary lifts to undeserved importance a step in the administrative procedure which in most instances can be satisfied without imposing undue burdens upon either litigant or administrative body. ${ }^{66}$

A somewhat wavering course has been charted in the treatment of cases in which it is alleged that the administrative body has expressed an unfavorable attitude towards the litigant. In Gilchrist r'. Interborough Rapid Transit Company, the plaintiff applied to a New York Commission for a higher rate, and thereafter filed a bill alleging that the 5 cent fare was confiscatory. On the day that this suit was instituted the Transit Commission denied the petition for want of jurisdiction. Although it appeared that the Commission "had long held the view that it lacks power to change the five cent rate established by contract," the United States Supreme Court declared "the Interborough could not have resorted to a federal court without first applying to the Commission as prescribed by statute. And having made such an application it could not defeat orderly action by alleging an intent [on the part of the Commission]

53. Natural Gas Pipeline Co. v. Slattery, 302 U. S. 300, 311 (1937).

54. It may be urged that the requirement of a rehearing with respect to the cxercise of a quasi-legislative function in an initial informal hearing is more justifiable than in the case of an original quasi-judicial hearing where the issues may have been more thoroughly canvassed. An unvarying quantum of deliberation is not an unfailing attribute of either type of hearing. Attention is called to the trend towards a thorough sifting of the facts as a preliminary to administrative rule-making. See Fuchs, Proceduri in Administrative Rule-Making (1938) 52 HARv. L. REv. 259, 268.

55. But see Southland Industries v. Federal Communications Commission, 99 F. (2d) 117, 121 (App. D. C. 1938): "This is not and should not be an arbitrary requirement. Whether a petition for rehearing should be filed in a particular case must be decided on the merits as each case arises." Note that the Communications Act involved in this case declares that a party may apply for a rehearing. The language of the statutes citcd supra note 51 appears to preclude any exercise of discretion.

56. See Dobie, Federal Procedure (1928) 748 , for the practice of taking exceptions before the federal master to his tentative report, thus affording him an opportunity to correct his errors. 
to deny the relief sought." 57 In short, despite clear evidence that the Commission felt itself powerless to decide in favor of Interborough, the Court emphasized the need for prior resort to the Commission in the interest of orderly formal action. Subsequently, however, in City Bank Company v. Schnader, the Supreme Court adopted a seemingly antithetical position without mentioning the Gilclirist case, saying:

"In view of what has been said, the appellant's cause of action in equity will not, strictly speaking, arise until an appraisement is made and certified to the Department of Revenue and notice of the fact is given appellant. However, in view of the allegations of the bill, we are not inclined to hold the suit premature. The bill charges that the Secretary of Revenue has refused to issue a waiver of tax, and that the Attorney General has notified the appellant and the State's appraiser the property is subject to the tax, and the appellant's claim for exemption will be denied. . . . The action the legality of which is challenged thus appears sufficiently imminent and certain to justify the intervention of a court of equity." 53

It is difficult to reconcile this pronouncement with the Gilchrist case. To be sure the Schnader case rests upon the threat of illegal action by officers of the state, but irreparable injury may proceed as well from an official refusal to relieve against continuing illegal confiscation.

One may be permitted to question the wisdom of basing judicial action upon informal administrative pronouncements, clues to which are derived from expressions of opinion and other unofficial sources. There is need to re-examine the basis of these cases in the light of the tendency to insist in the rehearing cases upon an application to the administrative body for a rehearing as a prerequisite to judicial relief. If it be deemed sound policy to give the administrative body an opportunity to reconsider and perhaps to modify its decision formally announced after presumably mature deliberation, how much more important is it that a board should not, merely because it has ventured an informal opinion, be deprived of the chance to hear argument, take the matter under advisement, and record its judgment in proper form. The likelihood that an administrative body may, after a formal hearing, modify a prior informal adverse opinion is at least as great as the possibility of inducing that tribunal to withdraw its considered judgment in the course of a rehearing. ${ }^{59}$

57. 279 U. S. $159,208,211$ (1929).

58. 291 U. S. 24, 34 (1934). Exhaustion has been dispensed with where declarations of intentions adverse to the claims of complainants were made at the end of negotiations or during the course of an administrative hearing. See Procter \& Gamble Distributing Co. v. Sherman, 2 F. (2d) 165,167 (S. D. N. Y. 1924); Interstate Natural Gas Co. v. Gully, 8 F. Supp. 174 (S. D. Miss. 1934).

59. One court taxed costs against a plaintiff who failed to exhaust the administrative remedy on the ground that the administrative body had expressed an adverse opinion, 
II.

Litigants have often successfully sought to escape the sweep of the exhaustion doctrine on the ground that the administrative agency was acting without jurisdiction, either because the particular case was allegedly outside the subject matter, or because the attempt to confer atthority on the administrative body was claimed to be unconstitutional. The frequent judicial rejection of the exhaustion rule under such circumstances sprang from the influence of the theory of ultra vires. It was an outgrowth of the conception that an administrative body exercises limited authority and is to be strictly confined within the bounds of that authority. Proceeding from this premise, a court felt free to ascertain for itself whether the litigant came within the scope of that authority; and a litigant outside the jurisdiction conferred was deemed free to ignore the administrative procedure and with it the requirement of exhaustion. ${ }^{00}$ Thus a Porto Rican was not required to exhaust the administrative remedy where an administrative agency was empowered to exclude aliens." Similarly, where the jurisdiction of the board was confined to transactions in interstate commerce, the courts found that a litigant who was engaged solely in intrastate commerce, or in local manufacturing, was outside the jurisdiction of the board and therefore not bound to exhaust the administrative procedure. ${ }^{62}$

The need, in the interest of orderly procedure, for abandoning the "authority" premise as a test for the application of the exhaustion requirement, was perceived by Mr. Justice Holmes as long ago as 1904. In United States $v$. Sing Tuck, ${ }^{63}$ a habeas corpus proceeding which involved the power to exclude an alien, petitioner objected that the act was not intended to apply to one who was a citizen. But, replied Mr. Iustice Holmes, the act

"points out a mode of procedure which must be followed before there can be a resort to the courts. In order to act at all the executive officer must decide upon the question of citizenship. If his jurisdiction is subject to being upset, still it is necessary that he should proceed if he decides that it exists. An appeal is provided by the statute. The first mode of attacking his decision is by taking that appeal. . . .

"for the reason that, had it proceeded in an orderly and reasonably thorough manner, the occasion for the present suit would probably never have arisen." Air-way Electric Appliance Co. v. Archer, 279 Fed. 878, 891 (S. D. Ohio 1922).

60. Dickinson, Administrative Justice and the Suprearacy of LalW (1027) 309; Stanley v. Supervisors of Albany, 121 U. S. 535, 550 (1887).

61. Gonzales v. Williams, 192 U. S. 1, 15 (1904).

62. Darger v. Hill, 76 F. (2d) 198, 200 (C. C. A. 9th, 1935) : Royal Farms Dairy v. Wallace, 8 F. Supp. 975 (D. Md. 1934); Eagle-Picher Lead Co. va Madden, 15 F. Supp. 407, 409 (N. D. Okla. 1936).

63. 194 U. S. 161 (1904). 
"We perfectly appreciate, while we neither countenance nor discountenance, the argument, drawn from the alleged want of jurisdiction. But while the consequence of that argument if sound is that both executive officers and the Secretary of Commerce and Labor are acting without authority, it is one of the necessities of the administration of justice that even fundamental questions should be determined in an orderly way." of

It is a singular example of the compartmentalized development of the exhaustion doctrine that subsequent cases involving similar objections to administrative jurisdiction of the particular controversy should make no mention of the Sing Tuck case. ${ }^{65}$ Although the case is not mentioned in Federal Trade Commission $v$. Claire Furnace Company, the doctrine of the Sing Tuck case is there restated; and if defections from the doctrine resulted in a number of injunctions against the National Labor Relations Board, ${ }^{66}$ it was none the less adhered to by most of the Circuit Courts of Appeal, and recently reaffirmed in IIyers $v$. Bethlehem Shipbuilding Company. ${ }^{67}$ It is therefore settled that where an administrative body is given jurisdiction of a certain subject matter, for example, "unfair practices affecting interstate commerce," the question of whether the individual litigant falls within that subject-matter is in the first instance for the board; hence the litigant must exhaust the administrative remedy before turning to the courts.

Although the exhaustion doctrine is a product of chancery, the rule has gradually been extended to suits at law, and that tendency is recognized and articulated in the Myers case. ${ }^{68} \mathrm{Mr}$. Justice Brandeis declared that "because the rule is one of judicial administration-not merely a rule governing the exercise of discretion-it is applicable to proceedings at law as well as suits in equity." 63

The Myers case also reminded the bar of another salutary rule which likewise has the effect of curtailing judicial interference with the preliminary administrative procedure of federal agencies, but which derives from a quite different source, the Congress. Congress may delimit the jurisdiction of federal courts, and it may, if it chooses, confide preliminary processes to administrative bodies, with appropriate judicial review

64. Id. at 167.

65. See, e.g., Mfyers v. Bethlehem Shipbuilding Corp., 303 U. S. 41, 51 (1933); Federal Trade Commission v. Claire Furnace Co., 274 L. S. 160 (1927).

66. See Eagle-Picher Lead Co. v. Madden, 15 F. Supp. 407 (N. D. Otsla. 1936); Bendix Products v. Beman, 14 F. Supp. 58 (N. D. Ill. 1936); ases collected in Comment (1936) 22 Wash. U. L. Q. 81,90, n. 33.

67. The cases are collected at 303 U. S. 44, n. 1 (1938).

68. Miyers v. Bethlehem Shipbuilding Corp., 303 U. S. 41, 51, n. 9 (1938).

69. Anniston Mfg. Co. v. Davis, 301 U. S. 337, 343 (1937); First National Banls v. Weld County, 264 U. S. 450, 455 (1924); Hamerstrom v. Toy National Banl; 81 F. (2d) 628,636 (C. C. A. 8th, 1936). 
to satisfy the demands of due process. ${ }^{70}$ In contrast to the exhaustion doctrine, which is a product of judicial self-limitation and amounts to a refusal to exercise jurisdiction upon grounds resembling the requirements of equity jurisdiction, the rule of exclusive preliminary administrative jurisdiction presupposes a complete absence of judicial power to deal with the matter because of the legislative grant of exclusive juriscliction to an administrative body. Paradoxically, the rule had its genesis, not in an attempted legislative grant of exclusive primary jurisdiction, but in the self-denying attitude of the Supreme Court. For the Act involved in Texas \& Pacific Railway v. Abilene Cotton Oil Company ${ }^{71}$ purported to safeguard the common law remedies of shippers ; ${ }^{72}$ yet a shipper who had sued at common law to recover damages because of the exaction of unreasonable rates, admittedly a good common law action, was turned back to the Interstate Commerce Commission. The Court reasoned that the Commission was alone vested with power originally to entertain stuch proceedings, on the ground that the Act sought to secure uniform rates, and uniformity could be secured only if the Commission passed upon the reasonableness of the rates in the first instance. ${ }^{73}$

An attempt to escape from the necessity of preliminary resort despite the statutory grant of primary exclusive jurisdiction, on the ground that the litigant was without the ambit of that jurisdiction, was turned back in the pioneer case of Chamber of Commerce $\%$. Fedcral Trade Commission. ${ }^{74}$

"The real gist of the complaint here is that it is claimed, and with plausibility, that the chief petitioner is not subject to the jurisdiction of the Federal Trade Commission ... The law does not contemplate that commissions of this nature will act arbitrarily nor without probable cause. It is, of course, conceivable that they may do so; but such a possibility cannot justify this court in exceeding its statutory powers and authority. To do so would be to deny to the administrative and legislative branches of the government the powers and authority which have been conferred upon them . . . It may be desirable that the law should provide for a preliminary review of questions of jurisdiction either by the Circuit Courts of Appeals or by the District Courts; but, in the absence of such provision, we cannot assume that power."

70. Myers v. Bethlehem Shipbuilding Co., 303 U. S. 41, 48 (1938); Anniston Mfg. Co. v. Davis, 301 U. S. 337, 343-346 (1937).

71. 204 U. S. 426 (1907).

72. Id. at 438-439. And see 2 Sharfman, The Interstate Commerce Commisston (1931) 393.

73. Alpert, supra note 3 at 393,395, sees in the Abilcuc case the progenitor of the exhaustion doctrine. It has been observed that the rule of exhaustion reaches back at least to 1887. And of course exclusive administrative jurisdiction is far older. Sec Cary v. Curtis, 3 How. 236 (U. S. 1845) (see the issue as formulated at p. 253).

74. 280 Fed. 45,48 (C. C. A. Sth, 1922). 
With the teaching of the Federal Trade Commission cases in mind, Congress in express terms vested "caclusiz' $c$ " power to prevent "un fair practices affecting interstate commerce" in the National Labor Relations Board, subject to review by the Circuit Courts of Appeals. The effect of that exclusive grant of jurisdiction, the Supreme Court declared in Myers z'. Bethlehem Shipbuilding Corporation, was to deprive the District Courts of jurisdiction to enjoin hearings before the Board, and to vest the Board with power to determine in the first instance whether the particular controversy fell within the jurisdiction granted. ${ }^{75}$ To the argument that this was tantamount to a denial of constitutional rights, the Cuurt replied that "the contention is at war with the long settled rule of judicial administration that no one is entitled to judicial relief for a supposed or threatened injury until the prescribed administrative remedy has been exhausted." $"$ The fact that the exhaustion cases were thus cited to buttress the primary jurisdiction doctrine underscores the essential identity, for practical purposes, of both rules. It cannot matter that the rules employ a somewhat different dialectic when the net effect of either rule is that a court of equity will refuse to take jurisdiction, in the one case because it is by federal statute conferred upon an administrative body, and in the other because the presence of an administrative remedy defeats equity jurisdiction. With the extension of the exhaustion doctrine to courts of law, and the establishment of the non-discretionary nature of the rule, the sole real point of difference disappears.

Although the Mycrs decision reaffirms the power of an administrative body to determine in the first instance whether a case falls within the statutory grant of jurisdiction over a particular subject matter, that case sheds no light upon the situation in which the administrative jurisdiction in toto is challenged on constitutional grounds. Before the constitutionality of the National Labor Relations .Act was settled a number of the lower federal courts dispensed with the exhaustion requirement and passed on the constitutional question. ${ }^{78}$ Raising the ghost of ultra

75. House Committee Report, H. R. REp. No. 1147, 74th Cong., 1st Sess. (1935) 24. "Until such final [administrative] order is made the party is not injured, and camn tis heard to complain, as has been held in cases under the Federal Trade Cummissin in .Ict."

76. 303 U. S. 41,48 (1938).

77. Id. at 50 .

7S. Bethlehem Shipbuilding Corp. v. Mleyers, 15 F. Supp. 915, 918 (D. Mass. 1936): "It is no answer that the act provides for judicial review. The remedies of the aet fall with the other provisions of the act, if it be held unconstitutional in lobo." St.ut $y$. Pratt, 12 F. Supp. 864, 870 (W. D. Mo. 1935); El Paso Electric Co. v. Eellin,t, 15 F. Supp. 81, 90 (IW. D. Tex. 1936) ; Oberman and Co. v. Pratt, 16 F. Supp. \&87. 837 (W. D. Mo. 1936) ; Bendix Products Corp. v. Beman, 14 F. Supp. 58, (A. I). Ill. 1936). See also Hirsh v. Block, 267 Fed. 614, 618 (App. D. C. 1930); Comment (1938) 47 YALE L. J. 766, 776 ("But some of the earlier lower court decisiuns granted injunstions on the ground that the act was unconstitutional, while the contentiun in the .I virs case was that the Board lacked jurisdiction. An argument may perhaps still be made 
vires, distinguished counsel in one case argued that "the act is unconstitutional in its entirety; that the board accordingly has not any authority whatsoever; and that therefore complainant need not avail itself of the remedies provided by an invalid statute before seeking relief in the courts $" 70$ But an allegation of unconstitutionality without more has been held insufficient to invoke equitable aid or relieve from the exhanstion requirement $;{ }^{80}$ and the possibility of raising the constitutional question in enforcement proceedings brought by the administrative body affords an adequate legal remedy. ${ }^{81}$ This is not to say that the exhaustion doctrine is limited to instances in which the constitutional question may be raised in such enforcement proceedings, for the Supreme Court has on several occasions applied the broader "rule of judicial administration that no one is entitled to judicial relief for a supposed or threatened injury until the prescribed administrative remedy has been exhausted" 82 to situations where the jurisdiction of the administrative body was assailed on constitutional grounds in other than enforcement proceedings.

Thus, in Lawrence v. St. Louis-San Francisco Railway Company, the railroad, ignoring a state statute which required administrative permission for a change of division points, instituted such a change and sought to enjoin interference by the state commission on the ground that the attempted state regulation was in violation of the commerce clause, and that the Commission was in consequence without jurisdiction. Reversing the injunction granted by the trial court, the Supreme Court declared:

"No right or interest of the Railway would have been prejudiced by participating in the hearings before the Commission and awaiting the result thereof. The Railway would not thereby have waived its right to contest in the federal court the validity of the Oklahoma law." 83

In a similar situation, where it was alleged that a state statute, requiring permission by the state commission for the discontinuance of intrastate service by interstate trains, violated the commerce clause, the Supreme Court found "no occasion . . . to determine whether the Alabama statute

therefore that the Myers case does not preclude an injunction where the constitutionality of the whole act is in issue.")

79. Associated Press v. Herrick, 13 F. Supp. 897 (S. D. N. Y. 1936). But the argument proved unavailing.

80. Id. at 898 and cases there cited. See also Mathews v. Rodgers, 284 U. S. 521, 525 (1932); Dupont de Nemours \& Co. v. Boland, 85 F. (2d) 12, 14 (C. C. A. 2d, 1936); Paramino Lumber Co. v. Marshall, 1S F. Supp. 645, 647 (W. D. Wash. 1937).

81. Dalton Machine Co. v. Virginia, 236 U. S. 699, 701 (1915); Thomas v. Dennis, 8 F. Supp. 501, 502 (W. D. Wash. 1934); McDermott v. Bradford, 10 F. Supp. 661, 664 (W. D. Wash. 1935); Federal Trade Comm. v. Claire Furnace Co., 274 U. S. 160,174 (1927).

82. Myers v. Bethlehem Shipbuilding Corp., 303 U. S. 41, 50-51 (1938).

83. 274 U. S. 588,592 (1927). 
is obnoxious to the Federal Constitution" . . . "the carrier should not hare discontinued the intrastate service without first applying to the Commission for permission." $\$ 4$ There are several other cases in the Supreme Court, ${ }^{85}$ and a number of decisions in the lower federal courts, including sereral cases wherein the issue was presented to the Second and Seventh Circuit Courts of Appeal in connection with the National Labor Relations Act, ${ }^{86}$ which make manifest that an attack upon the jurisdiction of an administrative body on constitutional grounds should not cause a court of equity to dispense with the exhaustion requirement.

Some confusion, however, beclouds the applicability of the exhaustion doctrine to tax cases arising under similar circumstances. It would seem as if the question had been settled when the Supreme Court, in Gorham II Iantufacturing Company z'. State Tax Commission, ${ }^{\text {si }}$ demanded exhaustion of the administrative remedy despite the challenge to the state tax law upon constitutional grounds. But the Circuit Court of Appeals for the Eighth Circuit, in Buder \%. First National Bank, has distinguished the Gorham case on the ground that the complaint in the latter was "of invalid assessments under existing laws. Here the complaint is of an assessment under no law at all." 88 If there "was no law" continued the Court, "there was no jurisdiction to assess the shares of stock," and resort to the board was therefore deemed superfluous. This argument amounts to no more than a revival of the ultra rires test and represents a regrettable retrogression. The distinction taken in the Buder case seems, moreover, to be untenable, because the Gorham case clearly involves an attack upon the validity of the law under which the tax was assessed. ${ }^{80}$ If, in the

84. St. Louis-San Francisco Ry. v. Alabama Pub. Serv. Comm., 279 U. S. 560, 563 (1929).

85. See also Vandalia R. R. v. Public Serv. Comm., 242 U. S. 255, 261 (1916); Gorham Mfg. Co. v. State Tax Commission, 266 U. S. 265 (1924).

86. Clark v. Lindemann \& Hoverson Co., \&\& F. (2d) 59, 60 (C. C. A. 7th, 1937); DuPont de Nemours \& Co. v. Boland, 85 F. (2d) 12, 14 (C. C. A. 2d, 1936); Paramino Lumber Co. v. Marshall, 18 F. Supp. 645, 647, 648 (W. D. Wash. 1937); Associated Press v. Herrick, 13 F. Supp. 897 (S. D. N. Y. 1936); Thomas v. Dennis, 8 F. Supp. 501, 502 (W. D. Wash. 1934); MeDermott v. Bradford, 10 F. Supp. 661, 663, 664 (W. D. Wash. 1935) ; United States F. \& G. Co. v. Blankenhorn, 22 F. (2d) 574 (N. D. Cal. 1927). And see Postal Telegraph-Cable Co. v. Fremont, 255 U. S. 124, 123 (1921), where prior administrative resort was required despite the complaint that the state tax imposed a burden upon interstate commerce.

87. 266 U. S. 265 (1924).

88. 16 F. (2d) 990,993 (C. C. A. Sth, 1927) cert. denied, 274 U. S. 743 (1927) (suit in equity), cited with approval in Southern Blid. R. R. v. City of Xew York, 86 F. (2d) 633,635 (C. C. A. 2d, 1936) (suit at law).

89. The gist of the constitutional objection to the Gorham tax was that "the slatulory" ratio... has resulted in an assessment against it of a tas based upon an allocated income greatly in excess of that in fact derived from the business of selling ware which it carried on within the state", that "such a tax upon income earned without the state by a foreign corporation engaged principally in interstate commerce, is a direct burden 
language of the Buder case, there was an "existing law" in the Gorham case, it was because the Supreme Court refused to inquire into the validity of the law in the absence of exhaustion of the administrative remedy; and by the same token, there "was no law at all" in the Buder case only because the court, disregarding the exhaustion requirement, plunged into the constitutional question.

Among the other arguments advanced to except attacks upon the constitutionality of administrative jurisdiction from the exhaustion doctrine is the contention that since an administrative body is tnlikely to invalidate the questioned enactment, preliminary administrative resort is not only futile, but may also create an estoppel. A District Court has held that one who would invoke administrative aid would estop himself from questioning the constitutionality of the act which conferred the jurisdiction, and on this ground dispensed with the exhaustion requirement. ${ }^{90}$ But estoppel can scarcely be said to arise out of a situation in which resort to an administrative tribunal is had under the compulsion of the exhaustion doctrine. ${ }^{01}$ The Supreme Court has said that a litigant who should have exhausted the administrative remedy "would not therely have waived its right to contest in the federal court the validity of the Oklahoma law." 92

If it be conceded that an administrative tribunal is unlikely to invalidate the enactment under attack the constitutional question can nonetheless be saved for judicial review. In addition to the rules of equity which preclude relief where no more than an assertion of unconstitutionality appears, or where the constitutional question may be subsequently raised, ${ }^{03}$

upon such commerce" (p. 269), and consequently, "that the provisions of this Articlo were in conflict with . . . the Commerce Clause of the Constitution." (p. 260). After summarizing the constitutional issues the Supreme Court said: "We are of the opinion, however, that, without reference to these constitutional questions, the bill was properly dismissed by the District Court because of the failure of the company to avail itself of the administrative remedy provided for the revision and correction of the tax:" Gorham Mfg. Co. v. State Tax Comm., 266 U. S. 265, 269 (1924). Becallie of the short statutes of limitation which accompany the administrative remedy in tax cases, a litigant's failure to exhaust the remedy may moan that he is left cutirely without remedy. See Stason, Itdicial Recieze of Tart Errors-Effect of Failuri to Resirt to Administrative Remedies (1930) 28 Mrch. L. REv. 637. Nevertheless, the ned in the interest of the public treasury for prompt action by tax payers who would avidd payment of taxes has induced the courts to apply the exhaustion doctrine more rigorously in tax cases than elsewhere, so that the principle has been termed by Stason, suptra, at forl, "administrative impregnability by estoppel". But this practice renders the Buder case even less explicable.

90. Hirsh v. Block, 267 Fed. 614, 618 (App. D. C. 1920); ste Commont (1935) 35 CoL. L. REv. $230,234$.

91. Obrecht-Iynch Corp. v. Clark, 30 F. (2d) 144, 146 (D. Md. 1929). And sce Comment (1934) 34 CoL. L. Rev. 1495, 1504, 1505.

92. Lawrence v. St. Louis-San Francisco Ry., 274 U. S. 588, 592 (1027).

93. Sitpra, p. 996. 
there are the requirements of comity and of orderly procedure. The requirements of orderly procedure, it has been noted, triumphed over the argument of ultra iires in cases which were alleged to lie outside the administrative jurisdiction of the subject matter; and it is rentured that there is no better reason for exempting an attack upon the administrative jurisdiction on constitutional grounds from the same requirements. ${ }^{94}$ The inconvenience and hardship to the litigant who is compelled to proceed with the administrative remedy are assuredly no less when he believes his case to be without the subject matter than when he assails the attempt to confer jurisdiction of the subject matter. Considerations of comity are at least equally compelling. Mr. Justice Brandeis, insisting on the exhaustion requirement although the constitutionality of a state act was in question, said:

"The federal power is paramount. But public interest demands that, whenever possible, conflict between the two authorities and irritation be avoided. To this end it is important that the federal power be not exerted unnecessarily, hastily, or harshly. It is important also that the demands of comity and courtesy, as well as of the law, be deferred to." 95

The argument for postponing judicial intervention in constitutional issues until preliminary resort is had to administrative remedies has added force when the attack is directed against allegedly unconstitutional acts of the administrative authorities, For example, a taxing officer may wrongfully discriminate against a taxpayer in levying assessments. Here the act of an administrative officer rather than his jurisdiction to act at all is assailed, and an appellate administrative tribunal can and presumably will correct the complained of wrong. ${ }^{96}$

A limitation upon the application of the exhaustion rule is identified with Oklahoma Gas Company z'. Russell. ${ }^{97}$ That case established the rule that where a tentative rate was allegedly confiscatory and no supersedeas was allowed pending completion of the legislative process, the exhaustion requirement was inapplicable. ${ }^{98}$ Tentative rates established by administrative fiat, it was reasoned, are final legislative acts as to the period during which they remain in effect pending the final determination; and if the rates prescribed are confiscatory, the company, deprived of a reasonable

94. "Whether the Act is valid, is not for the moment so impurtant as the fact that an adequate and orderly method is available for the determination of this question outside the equity powers of the court." Clark v. Lindemann \& Hoverson Co., \&8 F. (2d) 59, 60 (C. C. A. 7th, 1937).

95. Lawrence v. St. Louis-San Francisco Ry., 274 U. S. 588,595 (1927).

96. Hamerstrom v. Toy National Bank, 81 F. (2d) 628, 636 (C. C. A. Sth, 1936).

97. 261 U. S. 290 (1922).

98. The doctrine had been earlier formulated in Love v. Atchison, T. \& S. F. Ry., 185 Fed. 321 (C. C. A. 8th, 1911). And see Prendergast v. New York Telephone Co., 262 U. S. 43, 49 (1923) ; Pacific Telephone Co. v. Kuykendall, 265 U. S. 196 (1924). 
return upon its property during such period, is without remedy unless their enforcement should be enjoined. The limitation to which the Russell case gave rise has been extended to other than rate cases. ${ }^{90}$

Another exception to the exhaustion requirement is made where the very existence of the statute without more is said to affect and injure the complainant. Under these circumstances a litigant need not wait for threatened enforcement nor seek relief through administrative channels, but may at once invoke the assistance of equity. The rule had its inception in Pennsylvania $v$. West Virginia, which was concerned with a West Virginia statute requiring pipeline companies to satisfy intrastate needs before delivering gas to extrastate consumers, thereby interfering with the established current of interstate commerce. The Supreme Court, Holmes, Brandeis, and McReynolds, JJ. dissenting, held that the suit was not premature:

"This is a substantive provision whose terms are both direct and certain, and to which immediate obedience is commanded. No order of the commission is required to give it precision or make it obligatory, and it leaves nothing to the discretion of those who are to enforce it. On the contrary, it prescribes a definite rule of conduct and in itself puts the rule in force." 100

The arguments marshalled against this doctrine in the incisive dissent of Mr. Justice Brandeis seem to the mind of the writer unanswerable. The mere enactment did not constitute a threat to the flow of gas in interstate channels, declared Mr. Justice Brandeis, because no officer or court had power or jurisdiction under the statute to enforce performance by the gas-producing companies until primary resort was had to the commission and it acted upon the application.

"Until the Commission issues some order which purports to restrict in some way the discretion theretofore exercised by a corporation in respect to exports, every such concern is, under the Act of 1919 , legally as free to continue the transportation of gas to Pennsylvania and to Ohio as if that statute had not been passed.

"It is possible that the Commission would never be called upon to act. It is possible that if called upon, the Commission would reftse

99. Porter v. Investor's Syndicate, 286 U. S. 461, 469 (1932) ; Natural Gas Pipcline Co. v. Slattery, 302 U. S. 300 (1938) ; New Hampshire Gas \& Electric Co. v. Morse, 42 F. (2d) 49 (D. N. H. 1930). In the Slattery case, the Court demanded a supersedeas pending exhaustion of administrative remedies in a situation where heavy penaltics were imposed for a failure to disclose information requested by a State Commission. No mention was made of United States v. Clyde Steamship Co., 36 F. (2d) 691, 693 (C. C. A. 2d, 1929), and Bartlett Frazier Co. v. Hyde, 65 F. (2d) 350, 353 (C. C. A. 7th, 1933), cases which held that the case of penalties accruing for failure to obey the order of an administrative body differed in principle from a confiscatory rate or failure to obey a statutory mandate.

100. 262 U. S. 553, 593, 594 (1923). 
to make an order. It is possible that if the commission made an order, the order would be of such a character as not to affect seriously the interests which plaintiffs seek to protect. And it is possible that if any order were made, the state court would suspend its operation and would eventually annul it. . . . To overcome disobedience, or disregard, of an order, resort must, under the West Virginia statutes, be had to the courts . . the corporation is given opportunity to defend on the ground that the order is, for any reason, invalid."

In short, said the Justice, the objection is:

“. . . that the 'judicial stage' of the controversy had not been reached when these suits were begun; and, indeed, has not been since. See Prentis v. Atlantic Coast Line Co. . . . "101

The rule of the majority in the $W_{\text {cst }}$ Tirginia case was reiterated in Carter v. Carter Coal Company, ${ }^{102}$ but one may surmise from the record in Electric Bond \& Share Company v. Securities and Exchange Commis$\operatorname{sion}^{103}$ that the doctrine is perhaps on the wane. In the latter case the Electric Bond and Share Company filed a cross-bill asking for relief on the ground that the provisions of the Public Utility Holding Company Act of 1935 applicable to registered holding companies were irreparably injuring the defendants, even as unregistered holding companies under no injunctive compulsion to register, by placing a cloud upon their entire business. Section 4(a) of the Act made it unlawful for public utility holding companies to perform certain important functions in interstate commerce or through the mails unless they were registered. Registration, defendants claimed, would expose them to onerous restrictions which would constitute a direct invasion of their rights. Since dismissal of the cross-bill with the suggestion that they register so as to acquire standing to attack the registration provisions seemed clearly contrary to City Bank v. Schnader, ${ }^{104}$ and since the Commission must unavoidably apply the restrictions of the Act to the defendants, the defendants argued that the court should enjoin the enforcement "of a statute which immediately affects and injures the complainants by its very existence." 103

101. Id. at 612-616.

102. 298 U. S. 238, 287 (1936). In the Carler case suit was brought to enjoin the collection of a $15 \%$ tax imposed by the Bituminous Cosl Conservation Act of 1935. It had been urged in the District Court [Tway Coal Co. v. Glenn, 12 F. Supp. 570, 585 (W. D. Ky. 1935)] that the suit was premature because the defendant tax collector was without authority to collect taxes before the Commissioner of Internal Revenue assessed them. But the Supreme Court, quoting from Pennsyliania 2'. West Virginia, said that "The so-called tax of $15 \%$ is definitely imposed, and its exaction certain to ensue." See also Euclid v. Ambler Realty Co., 272 U. S. 365, 386 (1926).

103. 303 U. S. 419 (1938).

104. 291 U. S. 24,34 (1934).

105. Petitioner's Brief in the Electric Bond and Share case, pp. 120-121. See generally id. at 112-123. 
Success had attended a similar argument in the Court of Appeals for the District of Columbia, ${ }^{106}$ and it would seem that the Supreme Court might well have found it possible to apply the rule of the West Virginit and Carter cases which was pressed upon it, had the Court been so inclined. Instead, the Court chose to dismiss the cross-bill on the ground that it presented a. "variety of hypothetical controversies which may never became real." 107 This may possibly indicate that the rule of Pennsylitanic v. West Virginia has been overruled sub silentio, laying to rest a doctrine which has on more than one occasion misled the courts in the applicntion of the exhaustion rule. ${ }^{108}$ If so, the administrative process is put beyond the range of a barrage of injunctions such as for a time paralyzed the administration of the Public Utility Holding Company Act. ${ }^{109}$

Constitutional questions come before the courts charged with the tensions of political conflict, and onslaughts upon newly created administrative bodies frequently take on the aspect of political combat. In such an atmosphere judicial self-restraint becomes an act of statesmanship. The brief interval in which administrative tribunals attempt to sift matters confided to them may serve to discharge the atmosphere of political passions. Judicial interposition may become unnecessary for a number of reasons: the administrative body may decide in favor of the litigant, or it may decide that it has no jurisdiction. ${ }^{110}$ Every consideration which has impelled the Supreme Court to abstain from "entering unduly into an area of political conflict"111 emphasizes the utility of the exhatistion rule as a means of avoiding the premature expression of constitutional views. If it be suggested that the exemption of constitutional questions from the exhaustion requirement is merely a mode of accelerating the "test of the validity of a statute that sooner or later will be tested, the court's whole history of avowals against anticipating adjudication and the profound conceptions of government on which they are based, give conclusive answer." 112

106. North American Co. v. Landis, 85 F. (2d) 398, 401 (App. D. C. 1936) : "That the rights of the plaintiffs in the present cases would suffer by reason of the stay granted is apparent, since the very existence of the act, whether they register under it or not, must of necessity affect materially the conduct of their business during the pendency of these suits."

107. 303 U. S. 419,443 (1938).

108. See Yarnell v. Hillsborough Packing Co., 70 F. (2d) 435, 438 (C. C. A. 5th, 1934) ; El Paso Electric Co. v. Elliott, 15 F. Supp. 81, 85 (W. D. Tex. 1936) ; McDermott v. Bradford, 10 F. Supp. 661, 665 (W. D. Wash. 1935).

109. See Frankfurter and Fisher, The Business of the Supreme Court at the Octolter Terms, 1935 and 1936 (1938) 51 HaRv. L. REv. 577, 616, n. 69.

110. See Gundling v. Chicago, 177 U. S. 183, 186 (1900).

111. Frankfurter \& Fisher, silpra note 109, at 623.

112. Id. at 629 . 
III.

A number of commentators, concluding that jurisdictional issues are reserved to courts, and regarding such issues as questions of law, deduce therefrom that the exhaustion requirement is confined to questions of fact. ${ }^{113}$ The Myers case establishes that questions of jurisdiction fall within the exhaustion doctrine, and in so far as such issues are remitted to administrative tribunals for preliminary determination, the exhaustion rule may be said to extend to questions of law. ${ }^{11-}$ The distinction between questions of law and fact as a test for the need of preliminary administrative resort is, however, employed in the Interstate Commerce Commission cases. Preliminary resort was dispensed with in Great Northern Railway Company v. Merchants Elezator Company because the problem of what construction "shall be given to a railroad tariff presents ordinarily a question of law ... "115 To the extent that the Interstate Commerce Commission Act purported to conserve common law remedies, it may be said that the courts retained concurrent jurisdiction. Inasmuch as the exclusive preliminary jurisdiction of the Interstate Commerce Commission was a creature of judicial fashioning in the interests of uniformity, the Supreme Court might set bounds to its self-limitation, retaining concurrent jurisdiction for the lower courts of questions of law. These cases, it is to be borne in mind, do not detract from the argument that equity jurisdiction is absent in the presence of an administrative remedy, because the mere fact that an issue of law is presented does not of itself suffice to confer jurisdiction in equity. Except for two earlier immigration cases, the employment of the "law" criterion has apparently been confined to the Interstate Commerce Commission cases; and the result in the latter cases at times leaves something to be desired. ${ }^{110}$

The early immigration cases stand on a somewhat different footing. In United States v. Sing Tuck ${ }^{117}$ a Chinese who claimed citizenship urged

113. See Comments (1938) 51 Harv. L. Rev. 1251, 1265, (1935) 35 CoL L. Rev. 230, 234; Alpert, supra note 3, at 395 .

114. The Myers case has been rationalized as an exception to the "rule" that questions of law are reserved to the courts, on the ground that there the question of jurisdiction involved an intricate question of fact. Comment (1938) 51 HaRv. L. REv. 1251, 1265. The distinction between law and fact is tenuous at best, and has been trenchantly criticized. Dickisisox, $o p$. cit. supra note 60 , at 55. To graft an exception upon that dubious distinction would entail an inquiry into the extent of the mixture of law and fact necessary to forestall exhaustion-confusion thrice confounded. For a case insisting on exhastion where the question of jurisdiction was a pure question of law, see South Porto Rico Sugar Co. v. Munoz, 28 F. (2d) 820,822 (C. C. A. 1st, 192S).

115. 259 U. S. 285,291 (1922).

116. In Great Northern Ry. v. Ky-Krisp Co., 4 F. Supp. 358, 365 (D. Minn. 1933), the court found that the question of whether Ry-Krisp is to be classed as a cooked cereal food or as bakery goods is one of fact which requires preliminary administrative resort. Whether young onions are "onions green" or "plant, strawberry, and vegetable" was deemed a question of law in American Ry. Express v. Price Bros., 54 F. (2d) 67 (C. C. A. 5th, 1932).

117. 194 U. S. 161 (1904). 
that he was without the ambit of a statute providing for administrative appeal in the case of an alien excluded from admission, and that in consequence, under Gonzales $v$. Williams, ${ }^{118}$ preliminary resort to the administrative procedure was unnecessary. Distinguishing the Gonzales case, Mr. Justice Holmes said:

"In Gonzales v. Williams . . . there was no use in delaying the issue of the writ until an appeal had been taken, because in that case there was no dispute about the facts but merely a question of law [is a Porto Rican an alien]. Here the issue, if there is one, is a pure matter of fact, a claim of citizenship." 110

The necessity for resorting to the administrative appeal was rested by Mr. Justice Holmes on the requirements of orderly procedure. But the statute did not purport to differentiate between questions of law and fact for purposes of administrative appeal, nor does the decision attempt to explain the impotency of the orderly procedure requirement with respect to questions of law. Possibly the distinction taken owes its inception to the necessity for escaping from the sweep of the broad statement in the Gonzales case that exhaustion is unnecessary in the absence of jurisdiction. Today, analysis in terms of primary exclusive jurisdiction might impel a court to decide that the administrative body had been given preliminary jurisdiction of both questions of law and fact. For it seems clear that both questions may be entrusted to administrative bodies for exclusive preliminary determination. An administrative remedy may be made exclusive if adequate judicial review is provided. ${ }^{120}$

Since Congress can and does confide the preliminary determination of questions of law to administrative agencies, it would seem that the application of the exhaustion doctrine, so closely allied to the rule of exclusive preliminary jurisdiction, should not be tested by the illusory distinction between questions of law and fact. The most pointed criticism of the exhaustion requirement in cases which primarily involve questions of law is that administrative bodies are untrained to handle them and the requirement is in this situation time-consuming and futile. ${ }^{121}$ But administrative agencies are, in fact, constantly grappling with questions of law, for they can scarcely proceed without interpreting the statutes which they are called upon to administer. And in the process of unceasing application and

118. 192 U. S. 1, 15 (1904). Gonzales, a native of Porto Rico, claimed to be wrongfully excluded by the commissioner of immigration. The Supreme Court found that she was not an alien and did not come within the act, and that consequently "the commissioner had no jurisdiction to detain and deport her by deciding the mere question of law to the contrary; and she was not obliged to resort to the Superintendent or the Secretary." Sce also Ex parte Koerner, 176 Fed. 478 (C. C. E. D. Wash. 1909).

119. 194 U. S. 161, 168 (1904).

120. Anniston Mfg. Co. v. Davis, 301 U. S. 337, 343-346 (1937) ; Myers v. Bethlehem Shipbuilding Corp., 303 U. S. 41, 48 (1938).

121. Stason, supra note 89 , at 667 . 
interpretation of these statutes they become steeped in the legal problems which cluster about the particular agencies. ${ }^{122}$ As against the possible waste of time attributable to inadequate administrative bodies, there must be balanced the waste inherent in litigating in an area that is not susceptible of sharp definition. Findings of ultimate fact subsume questions of law, and questions of law are rooted in and cannot be divorced from a strict appraisal of facts. To employ the tenuous law and fact distinction ${ }^{123}$ as the criterion for the application of the exhaustion requirement is inevitably to foster litigation. The need for orderly procedure, the requirements of comity, are no less urgent as to questions of law than questions of fact. It is in both cases desirable to have a simple, readily understandable rule of administration which will obviate the necessity for a judicial determination in each instance as to whether exhaustion is necessary.

IV.

But what of the expense to the litigant? Is lie to be subjected to the burdens of costly administrative hearings only to learn that the administrative body is without jurisdiction? And why increase those burdens by the delay and expense which attend administrative rehearings? Most rehearings will involve no more than emphasis by a litigant upon some error of factual or legal interpretation which an administrative body mayhave overlooked, and which it should have the opportunity to correct. Where the presentation of new evidence is relied upon, the considerations which favor an administrative hearing in the first instance are equally compelling with respect to the rehearing. ${ }^{124}$ Nor can the burden imposed upon the courts by litigation with respect to whether an application for an administrative rehearing is necessary be ignored, particularly when administrative bodies may in most cases deny such applications pro forma, thus foreclosing both expense to the litigant and burdensome litigation.

It may be assumed that the frequently recurring attacks on administrative jurisdiction of the subject matter will as often as not prove to be without foundation, with the result that the courts may find them-

122. See Securities and Exchange Commission y. Associated Gas \& Electric Cu, 98 F. (2d) 795, 798 (C.C.A.2d, 1938). See also Norwegian Nitrogen Products Ca. v. United States, 288 U. S. 294, 315 (1933); Skeen v. Lynch, 48 F. (2d) 1047, 1047 (C. C. A. 10th, 1931).

123. Dicknson, op. cit. supra note 60, at 55: 2 Smasfamax, op. cit. supra note 72, at 439.

124. Statutory recognition of these factors is found in $\$ 9(a)$ of the SEcrnities $A(T$ of 1933 [15 U. S. C. \$77i(a) (1934)] which provides: "If either party slabll apply to the court for leave to adduce additional evidence. . . the cuturt may urder such additional evidence to be taken before the Commission . . The Commission may modify its findings as to the facts, by reason of the additional evidence so taken . . ." See alsoSecurities Exchaxge Act of 1934, 15 U. S. C. $\$ 78 y$ (a) (1934); Punlic Utility Holdixg Coxpasy ACt of 1935, 15 U. S. C. $\$ 79 x$ (a) (Supp. 1937). 
selves burdened with procedural questions, half of which might be diverted at the outset. It cannot be clesirable to place the administrative process at the mercy of every fanciful jurisdictional attack. The expense to the litigant must yield, the courts have said, to the necessity of preserving orderly procedure, the need for preserving the efficacy of the administrative process. ${ }^{125}$ While it may be urged that constitutional attacks upon the basic jurisdiction of the agency may forever be put at rest in but one appeal to the courts, such issues are not always resolved in favor of the litigant; and in the interim the intention of Congress or of a State may for a considerable period be nullified. The administration of the Public Utility Holding Company Act of 1935 was perforce held in abeyance for about two and one-half years while the validity of the statute was being determined. ${ }^{126}$ In such a situation the cost to the litigant of preliminary resort to the administrative body is far ontweighed by the advantages that inhere in an effort to give some effect to the intent of Congress.

Judicial relief is today conditioned upon exhaustion of the administrative remedy largely because courts of equity believed that the presence of that remedy, like the availability of an adequate remedy at law, defeated equity jurisdiction. Further impetus was given to the development of the doctrine by the requirements of orderly procedture, by the necessity that "even fundamental questions should be determined in an orderly" way." ${ }^{127}$ To this requirement the counsels of comity gave added weight. Meanwhile, experience with the administrative process has gradually persuaded the courts that something is to be gained by enlisting the assistance of specialized tribunals for a preliminary sifting of the complicated technical problems that are a concomitant of an industrialized society. By insisting upon this preliminary process courts preserve themselves from an avalanche of litigation that might threaten to engulf them. ${ }^{128}$ The logic of the development of the rule demands a crystallization of its non-discretionary nature in all branches of the doctrine. The retention of discretion in the application of the rule constitutes a continuing invitition to litigation. It is this factor, more than any other, which has resulted in an incrustation of case-law about an essentially simple rule. Were the exhaustion requirement rigorously applied in each instance, much of this wasteful litigation would soon be cut off at the source.

125. Petroleum Exploration, Inc. v. Public Service Comm., 304 U. S. 209, 222 (1938); Heller Bros. Co. v. Lind, 86 F. (2d) 862, 864 (App. D. C. 1936); Bradley Lumber Co. v. National Labor Relations Board, 84 F. (2d) 97, 100 (C. C. A. 5th, 1936).

126. "Within a few months after the passage of the Act on August 26, 1935, a total of 58 suits were brought challenging the Act as unconstitutional . . ." FoURTH AN NUAL Report of Securities \& Exchange Commission (1938) 47.

127. United States v. Sing Tuck, 194 U. S. 161, 168 (1904).

128. For example, there were 8,213 complaint cases alone on the dockets of the National Labor Relations Board in the period from July 1, 1937, to June 10, 1938. 